DOI 10.37882/2223-2982.2021.03-2.11

\title{
МОТИВАЦИОННО-ЦЕННОСТНЫЙ КРИТЕРИЙ В СТРУКТУРЕ ГРАЖДАНСКОЙ ОТВЕТСТВЕННОСТИ БУДУЩЕГО ВОЕННОГО ЛЕТЧИКА
}

\section{MOTIVATIONAL AND VALUE-BASED CRITERION IN THE STRUCTURE OF CIVIL RESPONSIBILITY OF A FUTURE MILITARY PILOT}

\section{S. Goncharov}

Summary: In the article, on the basis of the analysis of current scientific literature, the idea is formulated and the author's definition of civil liability of a future military pilot is presented. The set of fundamental components of civil liability, including the liability of a future military pilot, is highlighted; it also emphasizes the priority of the motivational and value-based component in the structure of his civil liability. The identified motivational and value-based criterion and the corresponding indicators in the form of features of civil values and motivation for responsible behavior of a cadet-future military pilot are substantiated. The article considers universal and civil values as socially significant guidelines for creating pedagogical conditions in the educational process of a military institute for enrichment, filling with a new positive meaning of civil values in a cadet. The priority role of motivation in the structure of civil liability as an internal, stable motivator of a cadet, which determines the direction of his activity, initiative both in professional behavior and in civil actions in general, is revealed. The article also emphasizes the relevance of a systemic study and optimization of the process of purposeful education of future military pilot civil liability.

Keywords: civil liability of a future military pilot, motivational and valuebased criterion, civil values and motivation for responsible behavior of cadets-future military pilots.

\author{
Гончаров Сергей Александрович \\ Преподаватель, ФГКВОУВО «Краснодарское высшее \\ военное авиационное училище летчиков \\ имени Героя Советского Союза А.К. Серова» \\ s.a_goncharov@mail.ru
}

Аннотация: В статье на основе анализа актуальной научной литературы формируется представление и дается авторское определение гражданской ответственности будущего военного летчика. Выделяется совокупность основополагающих компонентов гражданской ответственности, в том числе будущего военного летчика; подчеркивается приоритет мотивационноценностного компонента в структуре его гражданской ответственности. 0босновываются выявленный мотивационно-ценностный критерий и соответствующие ему показатели в виде особенностей гражданских ценностей и мотивации ответственного поведения курсанта-будущего военного летчика. Рассматриваются общечеловеческие и гражданские ценности как социально-значимые ориентиры создания в образовательном процессе военного вуза педагогических условий для обогащения, наполнения новым позитивным смыслом гражданских ценностей у курсанта. Раскрывается приоритетная роль мотивации в структуре гражданской ответственности как внутреннего, устойчивого побудителя курсанта, определяющего направленность его активности, инициативности как в профессиональном поведении, так и в гражданских поступках в целом; подчеркивается актуальность системного исследования и оптимизации процесса целенаправленного воспитания гражданской ответственности у будущего военного летчика.

Ключевые слова: гражданская ответственность будущего военного летчика, мотивационно-ценностный критерий, гражданские ценности и мотивация ответственного поведения курсантов-будущих военных летчиков.

\begin{abstract}
-ражданская ответственность как свойство субъекта жизнедеятельности характеризует его «... способность соотносить внешние требования и собственные возможности личностно-оптимальным способом, способность к самостоятельному выбору, самодетерминации, саморазвитию, разрешению противоречий и трудностей жизни, самостоятельному построению жизненного пути» $[2$, с. 12].
\end{abstract}

В гражданской ответственности мы видим базис становления целостности и зрелости личности военного летчика, способной трудиться на благо общества, государства, консолидировать их, реализуя истинно гражданскую позицию. В соответствии со стандартами ФГОС ВПО одним из конечных результатов образовательной деятельности при подготовке военных летчиков явля- ется выпуск военных кадров с высоким уровнем гражданской ответственности и профессиональных качеств, обеспечивающих их квалификационную мобильность и непрерывное совершенствование личных и профессиональных качеств в условиях военной службы [9].

В настоящем исследовании решается задача формирования представления о сущности гражданской ответственности современного военного летчика и изучения показателей, оценочных характеристик мотивационноценностного критерия в структуре гражданской ответственности будущего военного летчика.

Учитывая неоднозначность точек зрения ученых на феномен «гражданская ответственность», отсутствие единого подхода к пониманию его сущности и содержа- 
ния, невыработанность четкой понятийной определенности термина в нормативно-правовых актах, в которых он используется в качестве смысловой категории, можно отметить его трактовку большинством исследователей как интегрального качества или совокупности определенных свойств личности [3, 5, 6, 8]. При этом общепринятая совокупность таких качеств, свойств отсутствует, а сами качества отличаются некоторым смыслом и содержанием, в зависимости от научных позиций авторов, обновляющихся целей и задач конкретного исследования.

Это оставляет простор для авторского вклада в изучение данного феномена и позволяет в настоящем исследовании понимать гражданскую ответственность как интегративное качество личности будущего военного летчика, характеризующее его морально-правовую культуру, проявляющуюся в способности личности выполнять свой нравственный долг с чувством собственного достоинства и законопослушности, способствующую развитию профессионально-важных качеств и компетенций, достижению самореализации в военнопрофессиональной деятельности.

Проведенный обзор научных исследований, касающихся проблемы изучения сути и различных аспектов гражданской ответственности личности (Т.М. Беспалова, И.В. Зубов, С.С. Корешков, А.В. Морозов, С.В. Патрушев, Т.А. Садчикова, Т.Г. Целуйкина и др.), позволяет в самом общем виде представить совокупность основополагающих компонентов гражданской ответственности, в том числе будущего военного летчика: мотивацию, социальные ценности, знания и действия, позитивное отношение к своим правам, обязанностям и требованиям общества.

Поскольку гражданская ответственность должна выражаться, в первую очередь, внутренним принятием, присвоением курсантом-будущим военным летчиком системы общечеловеческих ценностей и моральнонравственных отношений к обязанностям гражданина и профессионала перед обществом и государством, готовностью к их неукоснительному исполнению, то важнейшим компонентом в структуре гражданской ответственности военного летчика мы считаем мотивационно-ценностный. В качестве его оценочной характеристики следует рассматривать мотивационно-ценностный критерий и соответствующие ему показатели.

Мотивационно-ценностный критерий раскрывает особенности гражданских ценностей и мотивации ответственного поведения курсантов-будущих военных летчиков.

Ценности являются мотиваторами и регуляторами человеческой деятельности жизнедеятельности в целом, выступают силой воздействия на способ и характер ее осуществления; служат критериями оценки поступков окружающих людей. Согласно М.С. Кагану, ценности следует понимать как необходимую человеку культурную силу, взаимосвязанную и взаимодействующую с его потребностями в осуществляемых им актах жизнедеятельности [4].

Определяя облик нашего общества, ценности, их сущностные характеристики в значительной степени обусловлены его развитием. С другой стороны, гражданские ценности, создаваясь общественной системой, они далее выступают фактором его развития.

Присутствующий сегодня процесс демократического преобразования общества несет возможные утраты шкалы общественных, гражданских и даже общечеловеческих ценностей, актуализируя проблему истинных ценностных ориентиров личности. Поскольку от того, какими ценностями движима личность, обусловлено, в итоге, содержание и направленность системы высшего военного образования, с одной стороны, и внутренние ориентиры, и функциональные и межличностные отношения будущих военных летчиков в рамках военно-профессиональной деятельности и гражданского долга.

Общечеловеческие и гражданские ценности способны «приносить» человеку культуру, «очеловечивать»его и воспитывать ответственность за себя и окружающий мир, формировать у него должную меру участия в жизни общества. Необходимость поиска новых социально-значимых ориентиров, мотивационно-ценностных оснований обращает наше внимание на важность создания в образовательном процессе военного вуза педагогических условий, в которых у курсантов будут успешно формироваться, обогащаться, наполнятся новым позитивным смыслом гражданские ценности.

Одним из важнейших компонентов любой деятельности и поведения личности выступает мотивация - совокупность мотивов, как внутренних побудителей деятельности, придающих ей личностный смысл и значимость (С.Л. Рубинштейн) [7].

Мотивацию в структуре гражданской ответственности мы понимаем как внутреннее побуждение курсанта, которое определяет направленность его активности, инициативности как в профессиональном поведении, так и в гражданских поступках в целом, поскольку именно мотив определяет пространство целей и непосредственно побуждает деятельность каждой конкретной личности. Такое внутреннее побуждение курсанта к определенному типу поведения всегда связано с мотивацией, например ответственного/безответственного поведения и отражает сам предмет потребности и состояние её носителя-курсанта. 
Мотив, как некий обобщенный образ предметов, представляющих ценность для личности, управляет ее поведением, способствуя его организованности, направленности, активности, устойчивости и обеспечивая ответственность поведения [7].

Исследования показывают, что наличие такого личностного качества у человека как ответственность будет в полной мере характеризовать его поведение в жизнедеятельности. Говоря об ответственном поведении, следует понимать сознательное отношение курсанта к выполнению моральных и правовых норм, требований, которые предъявляют ему будущая профессия военного летчика и общество. Это неукоснительное исполнение курсантом взятых на себя обязательств и готовность держать отчет перед собой и внешними инстанциями за свои действия/бездействия и поступки.

Мотивация такого ответственного поведения может быть как внешней (общественное мнение, желание получить более высокую оценку в профессиональном сообществе или избежать возможного наказания и т.д.), так и внутренней (искренний интерес, личностный смысл, значимость и ориентация на успешный процесс и результат выполнения воинского долга для удовлетворения высших духовных, социальных потребностей личности курсанта). «То есть, речь идет о внутренней ответственности личности перед собой и другими ...; о готовности ... обеспечить развитие и использование всех своих потенциалов - интеллектуального, духовного, творческого и др. в наиболее полной мере» [1, с. 83].

Важно подчеркнуть, что внутренние мотивы приоритетны, так как связаны непосредственно с самим человеком и его отношением к своей деятельности. Поэтому в качестве личностного фактора, определяющего особенности ответственного поведения, психологи выделяют интернальность, т.е. внутренний локус контроля, определяющий внутренний тип атрибуции личности [2].

Не менее важным аспектом воспитания мотивации ответственного поведения у курсантов является его направленность и технологии на формирование у них устойчивых мотивов, т.е. основанных на профессиональных, образовательных, социальных потребностях кур- сантов, и не требующих никакого дополнительного подкрепления. Устойчивые мотивы существуют достаточно длительное время, так как изменения в мировоззрении, интересах, установках происходят редко и постепенно. В то время как неустойчивая мотивация обладает свойством быстрого изменения, сформированный мотив ответственного поведения курсанта, хотя не обеспечивает реализацию искомого поведения, но в значительной степени подготавливает его целенаправленность.

Концепт гражданской ответственности личности, в том числе военного летчика, недостаточно исследован современной педагогической наукой, при этом достаточно активно используется научно-теоретической литературе, в практических исследованиях [3, 5, 6, 8]. Интегрируя субъектные образования личности, смысло-содержательные аспекты военно-профессиональной деятельности и жизнедеятельности в целом, гражданская ответственность будущего военного летчика требует системного исследования, обязательным результатом которого станет выявление и описание совокупности всех взаимосвязанных, взаимообусловленных структурных элементов (компонентов), составляющих ее целостHOCTb.

Анализ научных исследований (И.В. Зубов, С.С. Корешков, А.В. Морозов, С.В. Патрушев, Т.А. Садчикова и др.), позволил нам представить в структуре гражданской ответственности военного летчика, наряду с отмеченным мотивационно-ценностным, когнитивный, отношенческий и регулятивно-деятельностный компоненты.

Дальнейший научный поиск будет направлен на изучение их содержательных, уровневых и функциональных характеристик, что позволит определить своеобразие, многогранность, изучаемого феномена, подчеркнуть динамичный характер гражданской ответственности военного летчика, порождающий в своем развитии каждый раз качественно иной уровень ее организации. Это актуализирует проблему оптимизации процесса целенаправленного воспитания гражданской ответственности особенно у будущих военных летчиков, поскольку их роль в поддержании безопасности государства и поддержании общественного порядка на территории страны особенно важна на сегодняшний день.

\section{ЛИТЕРАТУРА}

1. Абдалина Л.В., Рыжкова Э.Н. Некоторые аспекты исследования профессиональной ответственности преподавателя вуза // Вестник Воронежского государственного технического ун-та. 2014. №3.2. Т. 10. С.82-85.

2. Дементий Л.И. Ответственность как свойство субъекта жизнедеятельности: автореф. ... канд. пед. наук. Москва, 2005. 48 с.

3. Зубов И.В. Формирование гражданской ответственности курсантов вузов МЧС Россиив: автореф. ... канд. пед. наук. Воронеж, 2014. 24 с.

4. Каган М.С. Философская теория ценности. СПб., ТОО ТК: «Петрополис», 1996. 205 С.

5. Морозов А.В. Проблема гражданской ответственности молодежи в современном обществ // «Формирование гражданской идентичности молодежи на 
основе историко-культурного наследия как универсальной ценности, посвященной 100-летию образования ТАССР»: Международная научно-практическая конференция. 2019. С. 235-240.

6. Патрушев С.В., Кучинов А.М., Мирясова 0.А., Недяк И.Л., Павлова Т.В., Филиппова Л.Е. Формирование гражданской ответственности в России // Социологическая наука и социальная практика. 2020. Т. 8. № 1. С. 27-47. DOI: 10.19181/snsp.2020.8.1.7093.

7. Рубинштейн С.Л. Основы общей психологии. СПб.: Питер, 2002. 720 с.

8. Садчикова Т.А. Формирование гражданской ответственности старшеклассников в процессе волонтерской деятельности: автореф.... канд. пед. наук. Тамбов, 2009. 24 c.

9. Хамула Л.А., Левандровская Н.В. Персонифицированный подход к обучению иностранному языку курсантов военного вуза // Воздушно-космические силы. Теория и практика. 2020. № 15. С. 305-313.

( Гончаров Сергей Александрович (s.a_goncharov@mail.ru).

Журнал «Современная наука: актуальные проблемы теории и практики»

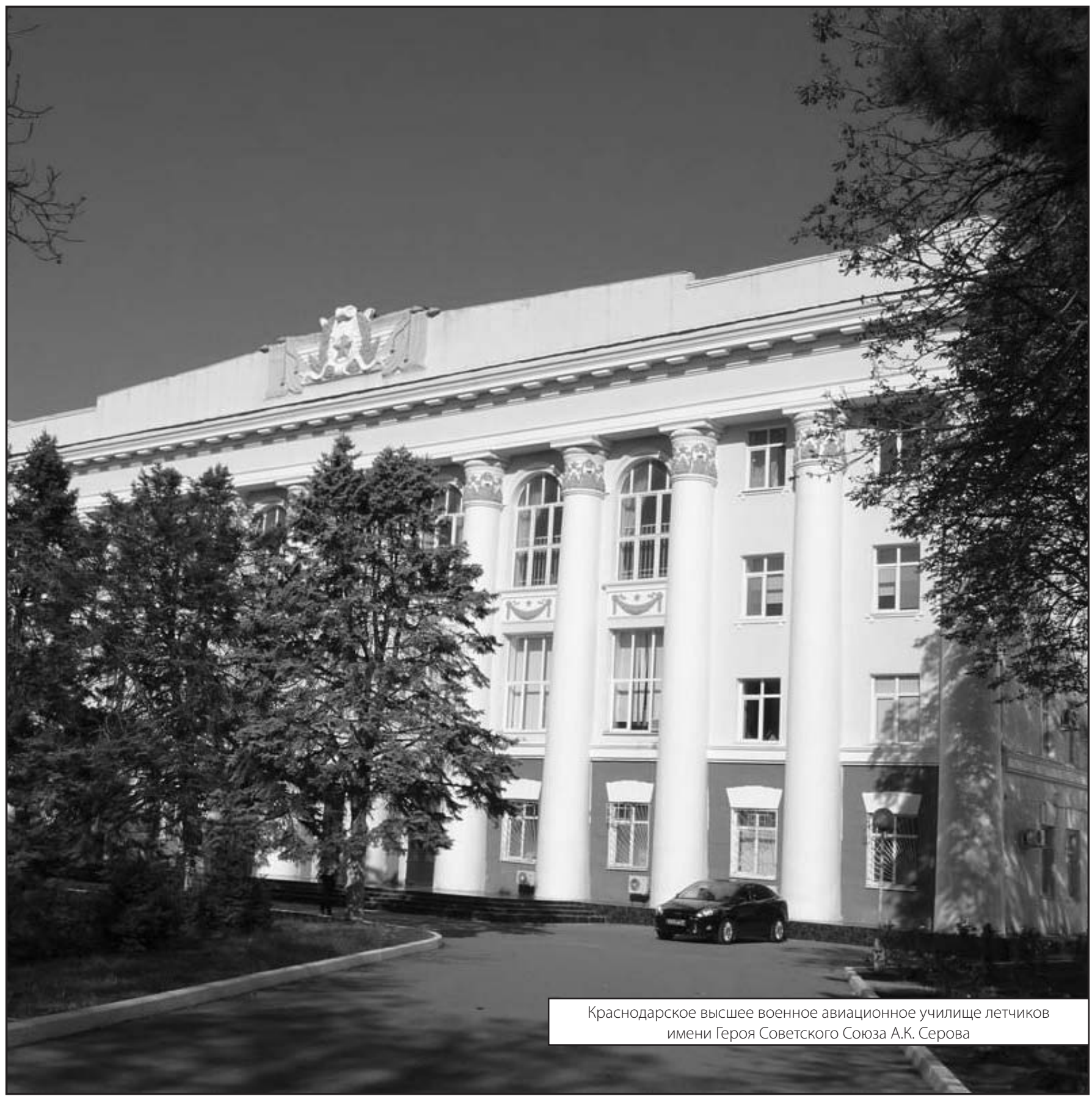

